\title{
A Novel GDAP1 Mutation 439delA is Associated with Autosomal Recessive CMT Disease
}

\author{
Domna-Maria Georgiou, Paschalis Nicolaou, David Chitayat, Pantelitsa Koutsou, \\ Riyana Babul-Hirji, Jiri Vajsar, Jillian Murphy, Kyproula Christodoulou
}

\begin{abstract}
Background: Charcot-Marie-Tooth (CMT) disease is the most common form of inherited motor and sensory neuropathy. Based on neurophysiological and neuropathological criteria CMT has been sub-classified into two main types: demyelinating and axonal. Furthermore, it is genetically heterogeneous with autosomal dominant, autosomal recessive (AR) and X-linked modes of inheritance. Thus far, seven genes have been identified in association with the demyelinating AR-CMT disease. We hereby report our clinical and molecular genetic findings in a consanguineous family with AR-CMT. Methods: Two young sisters with AR-CMT and other non-affected family members were clinically and electrophysiologically evaluated and then molecular genetic investigation was carried out in order to identify the pathogenic mutation. Results: Following an initial indication for linkage of the family to the CMT4A locus on chromosome 8, we sequenced the Ganglioside-induced differentiation-associated protein 1 (GDAP1) gene and identified a single nucleotide deletion in exon 3 that is associated with ARCMT in the family. Conclusions: We identified a novel GDAP1 439delA mutation that is associated with AR-CMT in a consanguineous family of Iranian descent with two affected young girls and a history in other members of the family.
\end{abstract}

RÉSUMÉ: Une nouvelle mutation 439delA du gène GDAP1 associée à la maladie de CMT récessive autosomique. Contexte : La maladie de Charcot-Marie-Tooth (CMT) est la forme la plus fréquente de neuropathie sensitivomotrice héréditaire. La maladie de CMT a été sous divisée en deux types principaux, le type démyélinisant et le type axonal, selon des critères neurophysiologiques et neuropathologiques. De plus, la maladie est hétérogène au point de vue génétique avec hérédité dominante autosomique, récessive autosomique (RA) et liée à l'X. Jusqu 'à maintenant, sept gènes associés à la maladie de CMT-RA démyélinisante ont été identifiés. Nous rapportons nos observations cliniques et moléculaires chez une famille consanguine atteinte de maladie de CMT-RA. Méthodes : Deux jeunes sœurs atteintes de maladie de CMT-RA et les membres non atteints de la famille ont subi une évaluation clinique et électrophysiologique ainsi qu'une étude de génétique moléculaire afin d'identifier la mutation en cause. Résultats : Les études initiales indiquaient un linkage au locus CMT4A sur le chromosome 8 dans la famille. Nous avons donc séquencé le gène GDAP1 et nous avons identifié une délétion d'un seul nucléotide dans l'exon 3 associée au CMT-RA dans cette famille. Conclusions : Nous avons identifié une nouvelle mutation, 439delA dans le gène GDAP1, associée au CMT-RA dans une famille consanguine de descendance iranienne ayant une histoire familiale positive et dont deux jeunes filles sont atteintes de la maladie.

Can. J. Neurol. Sci. 2006; 33: 311-316

Charcot-Marie-Tooth (CMT) disease is the most common inherited peripheral neuropathy with an incidence of $\sim 1 / 2500$ in the general population. It is characterized by progressive weakness due to muscular atrophy with sensory loss more severely affecting the hands and feet. ${ }^{1}$ There are two major pathophysiological types of CMT: the demyelinating form (CMT1, CMT4) characterized by decreased motor nerve conduction velocities (MNCV) and the axonal form (CMT2) that is characterized by normal or slightly reduced $\operatorname{MNCV}(\mathrm{s}){ }^{2}$ Both
From the Molecular Genetics Department D (DMG, PN, PK, KC), The Cyprus Institute of Neurology and Genetics, Nicosia, Cyprus; Division of Clinical and Metabolic Genetics, Department of Pediatrics (DC, RBH, JM); Division of Neurology, Department of Pediatrics (JV), The Hospital for Sick Children, University of Toronto, Toronto, ON, Canada.

Received June 20, 2005. AcCePted In FinAl FORM ApriL 8, 2006. Reprint requests to: Kyproula Christodoulou, Molecular Genetics Department D, The Cyprus Institute of Neurology and Genetics, 6 International Airport Ave., P.O. Box 23462, 1683 Nicosia, Cyprus. 
Table: Autosomal recessive Charcot-Marie-Tooth clinical types, loci and genes

\begin{tabular}{|c|c|c|c|c|c|}
\hline Type & OMIM & Chromosome & Gene & Clinical characteristics & References \\
\hline CMT4A & $\# 214400$ & $8 q 13-q 21.1$ & GDAP1 & demyelinating severe neuropathy of childhood & 5,22 \\
\hline CMT4B1 & $\underline{\# 601382}$ & $\underline{11 \mathrm{q} 22}$ & MTMR2 & $\begin{array}{l}\text { demyelinating neuropathy - presence of focally folded } \\
\text { myelin sheaths }\end{array}$ & $23-25$ \\
\hline CMT4B2 & $\# 604563$ & $\underline{11 \mathrm{p} 15}$ & $\mathrm{SBF} 2$ & $\begin{array}{l}\text { early-onset demyelinating CMT with focally folded } \\
\text { myelin sheaths }\end{array}$ & $26-28$ \\
\hline CMT4C & $\underline{\# 601596}$ & $\underline{5 q 32}$ & SH3TC2 & $\begin{array}{l}\text { demyelinating CMT, nerve biopsy findings of large } \\
\text { cytoplasmic extensions of Schwann cells }\end{array}$ & $29-31$ \\
\hline CMT4D & $\# 601455$ & $\underline{8 q 24.3}$ & NDRG 1 & demyelinating CMT with deafness (Lom) & 32,33 \\
\hline CMT4E & $\# 605253$ & $\underline{10 q 21.1-q 22.1}$ & EGR2 & demyelinating congenital hypomyelinating neuropathy & 34 \\
\hline CMT4F & $\underline{\# 145900}$ & $19 q 13.1-q 13.3$ & PRX & demyelinating CMT & 35,36 \\
\hline CMT4G & $\% 605285$ & $\underline{10 q 23.2}$ & unknown & demyelinating severe disabling form of CMT (Russe) & 37 \\
\hline CMT4H & $\% 609311$ & $12 \mathrm{p} 11.21-\mathrm{q} 13.11$ & unknown & severe demyelinating CMT & 38 \\
\hline CMT2B 1 & $\# 605588$ & $1 \mathrm{q} 21.2-\mathrm{q} 21.3$ & LMNA & axonal CMT & 39,40 \\
\hline CMT2B2 & $\% 605589$ & $\underline{19 q 13.3}$ & unknown & axonal CMT & 41,42 \\
\hline $\mathrm{CMT} 2 \mathrm{H}$ & $\underline{607731}$ & $8 \mathrm{q} 21.3$ & unknown & axonal CMT with pyramidal features & 43 \\
\hline CMT2K & $\# 607831$ & $\underline{8 \mathrm{q} 13-\mathrm{q} 21.1}$ & GDAP1 & early onset axonal CMT & 7,8 \\
\hline $\mathrm{CMT} 2+\mathrm{VCP}$ & \#607706 & $\underline{8 q 13-q 21.1}$ & GDAP1 & axonal CMT with vocal cord paresis & 6,44 \\
\hline CMTRIA & $\# 608340$ & $8 \mathrm{q} 21$ & GDAP1 & intermediate CMT & 9,10 \\
\hline
\end{tabular}

conditions can have autosomal dominant, X-linked or autosomal recessive (AR-CMT) modes of inheritance. ${ }^{3,4}$ The various clinical forms of AR-CMT that have been described and the corresponding genes that have been identified or mapped are shown in the Table.

Ganglioside-induced differentiation-associated protein 1 (GDAP1) gene mutations were initially reported in two phenotypically different groups of AR-CMT families. Baxter et $\mathrm{al}^{5}$ reported GDAP1 gene mutations in demyelinating AR-CMT families, whereas Cuesta et $\mathrm{al}^{6}$ reported GDAP1 gene mutations in axonal AR-CMT families. Since then, additional GDAP1 mutations in families from various ethnic groups were reported. ${ }^{7-18}$ Electrophysiological and neuropathological findings of patients revealed that GDAP1 mutations contribute to axonal, demyelinating or intermediate AR-CMT occasionally associated with hoarseness or vocal cord paralysis. Phenotypic variability within the same family has also been reported. ${ }^{12}$ Ganglioside-induced differentiation-associated protein 1 mutations are currently reported in OMIM under demyelinating AR-CMT (CMT4A; MIM 214400), axonal AR-CMT (CMT2K; MIM 607831), axonal AR-CMT with vocal cord paresis (CMT2 + VCP; MIM 607706) and intermediate A AR-CMT (CMTRIA; MIM 608340).

We hereby report a novel GDAP1 gene mutation in a consanguineous AR-CMT family of Iranian descent.
Electrophysiological and neuropathological findings of the proband are suggestive of a demyelinating polyneuropathy whereas the electrophysiological data of her younger sister are indicative of an axonal polyneuropathy.

\section{Patients and Methods}

The proband (IV-2) as well as five other members of the family (III-1, III-2, IV-1, IV-3 and IV-4) were clinically examined. Nerve conduction studies were performed on the proband (IV-2), her younger affected sister (IV-3) and the parents (III-1 and III-2). A sural nerve biopsy investigation was done on the proband.

The proband is a 9-year-old girl who was born following an uncomplicated pregnancy and delivery. At the age of $2^{1 / 2}$ years she was noted to walk with dropped feet and difficulties in running with frequent falls. At 3 years she was noted to have contractures of her fingers although at that stage she could still open her hands fully and use her fingers. Electrophysiological studies done on the median nerve at the age of $3^{3 / 12}$ revealed slow nerve conduction velocity $(\mathrm{NCV})$ with left posterior tibial motor conduction velocity of $28.7 \mathrm{~m} / \mathrm{sec}$ (amplitude: $0.02 \mathrm{mV}$ ), left deep peroneal showing no response with supramaximal current, left sural sensory conduction of $32.5 \mathrm{~m} / \mathrm{sec}$ (amplitude: $7.9 \mu \mathrm{V}$ ) and left median motor conduction velocity of $33.7 \mathrm{~m} / \mathrm{sec}$ 
(amplitude: $0.7 \mathrm{mV}$ ). The pattern was consistent with demyelinating sensory motor polyneuropathy with diffuse slowing, and temporal dispersion, but no conduction blocks. An MRI of the whole spine done at 4 years of age showed slight enhancement of several left-sided nerve roots in the region of the cauda equine consistent with polyneuropathy. No other spinal cord abnormalities were detected. Her CSF showed normal protein and glucose.

Over the next few years she continued to loose her muscle strength mostly distally with mild atrophy and clawing of her hands. She also developed mild ankle contractures bilaterally with prominent calf atrophy and required ankle bracing for walking. Her gait became unstable and she developed Gower's sign. Left sural nerve biopsy at the age of $3^{9 / 12}$ showed evidence of thinly myelinated axons with several axons showing more than one layer of Schwann cells processes suggestive of early onion bulbing. However, overall onion bulbs were not prominent. There was also a sparse inflammatory infiltrate; the findings were suggestive of a demyelinating neuropathy.

Her sister (IV-3) who is 6-years-old was also born following an uncomplicated pregnancy and delivery. Initial symptoms were at the age of 2 years with dropped feet and clumsiness while walking and running with difficulties in climbing and descending stairs. She also had difficulties in grasping objects, buttoning and zipping. Overall her clinical manifestations were the same as in her sister and the progression of her condition was at the same pace as in her sister. Electrophysiological studies carried out at the age of $1^{8 / 12}$ revealed relatively preserved NCV of the median motor nerve $(42.3 \mathrm{~m} / \mathrm{sec})$ with decreased amplitude $(0.78 \mathrm{mV})$. The tibial nerve studies showed low response of $0.64 \mathrm{mV}$ with normal velocity at $45 \mathrm{~m} / \mathrm{sec}$ suggestive of developing neuropathy. Nerve conduction studies of both parents (III-1 and III-2) were normal.

\section{Genotyping}

Individuals III-1, III-2, IV-1, IV-2, IV-3 and IV-4 were genotyped at microsatellite polymorphic marker loci, spanning the candidate AR-CMT loci (CMT1A: D17S122, D17S261; CMT1B: CRP, APOA, SPTA; CMT4A: D8S551, D8S548, D8S164, D8S64; CMT4B1: D11S1332, D11S919, D11S917; CMT4B2: D11S4149, D11S1329, D11S1999, D11S4189; CMT4C: D5S643, D5S463, D5S402, D5S638; CMT4D: D8S558, D8S378, D8S529, D8S256; CMT4E: D10S1220, D10S1225, D10S1432; CMT4F: D19S897, D19S223, D19S420), following previously described methodology. ${ }^{19}$

\section{Linkage and Haplotype Analyses}

Two-point linkage analysis between the disease and each of the above marker loci was performed, using MLINK of the LINKAGE package of programs. ${ }^{20}$ Haplotypes of individuals were constructed manually following the order in which the marker loci are mapped at the corresponding chromosomal region.

\section{Mutation Analysis}

Mutation screening of the GDAP1 gene was performed using previously described PCR primer sets covering the six coding exons. ${ }^{6}$ Amplification products were sequenced in both directions using the CEQ DTCS kit and the Beckman Coulter CEQ analyser. The resulting data were automatically compared with the normal GDAP1 sequence as listed in the GenBank database (Accession: NT_008183, Region: 27105194..27121658, Version: NT_008183.16, GI: 29824571 of 28 April 2003), using the CEQ8000 investigator software. Direct mutation detection in all available family members was performed by PCR amplification of exon 3 and HincII restriction enzyme analysis.

\section{RESULTS}

The family was initially screened for linkage at the known CMT1 and CMT4 loci. Linkage to the CMT1A, CMT1B, CMT4B1, CMT4B2, CMT4C, CMT4D, CMT4E and CMT4F loci was excluded and an indication for linkage to the CMT4A1 locus was observed with a maximum lod score of 1.67 at $\theta=0.00$ for locus D8S551. Haplotype analysis also supports linkage to the CMT4A locus (Figure 1).

Mutation screening of the entire coding and promoter regions of the GDAP1 gene revealed a homozygous one base-pair deletion of $\mathrm{A}$ at position 439 (439delA) in the third exon of the gene. It is predicted that this deletion leads to a frameshift mutation at codon Thr147 and a premature stop at codon 151

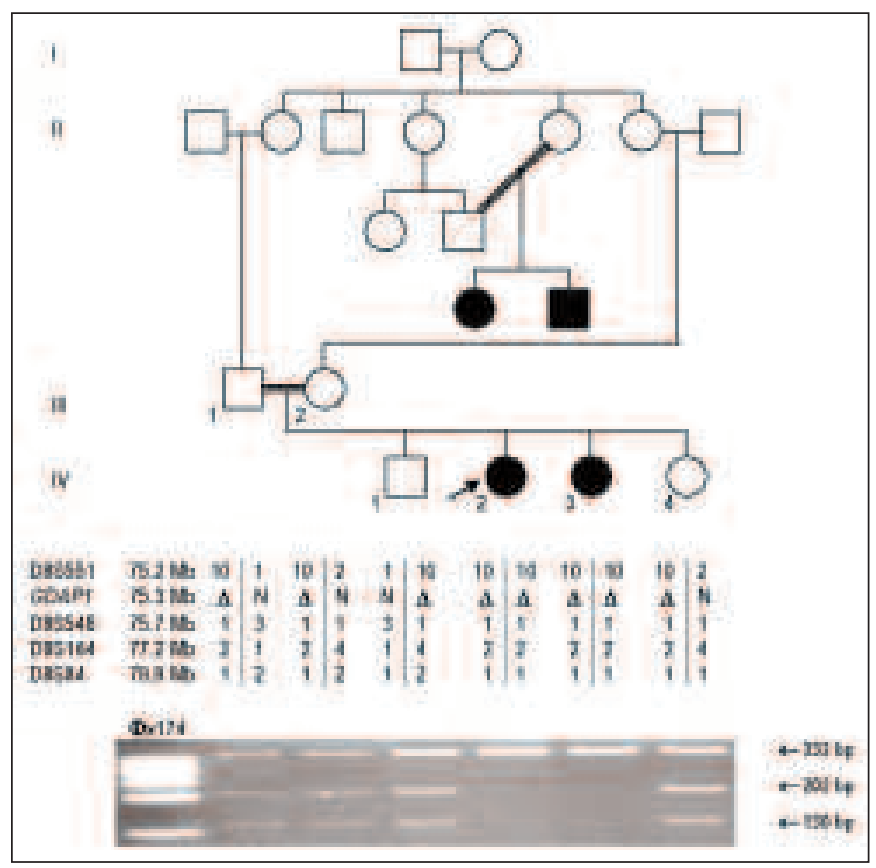

Figure 1: Pedigree of the consanguineous AR-CMT family of Iranian descent. Haplotypes are shown under the corresponding available individuals (III-1, III-2, IV-1,IV-2, IV-3 and IV-4). Mutation detection by $P C R$ amplification of GDAP1 exon 3 and HincII restriction enzyme digestion is depicted under the haplotypes. Homozygous 439delA individuals (patients IV-2 and IV-3) give a single band of $332 \mathrm{bp}$, whereas heterozygous N/439delA individuals (III-1, II-2, IV-1, IV-4) give three bands of $332 \mathrm{bp}, 202 \mathrm{bp}$ and $130 \mathrm{bp}$. Homozygous normal individuals (not shown here) give two bands of $202 \mathrm{bp}$ and $130 \mathrm{bp}$. 


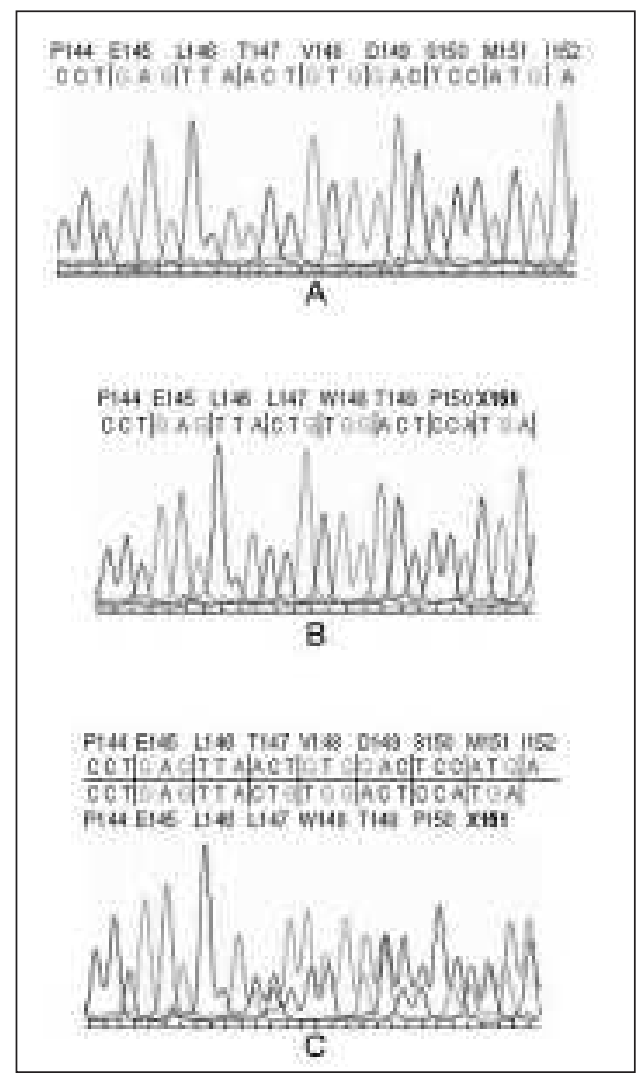

Figure 2: Sequence analysis data of the relevant GDAP1 region. Part A shows the DNA and amino acid sequence of a normal control individual. Part B shows the DNA and amino acid sequence of the proband, homozygous for the 439delA mutation. Part $C$ shows the sequence data obtained from a carrier of the 439delA mutation (individual III-1) and the predicted amino acid sequences.

(T147fsX151) (Figure 2). The deletion at the DNA level destroys a HincII restriction endonuclease cutting site; therefore it was used to trace the mutation in all family members. PCR amplification of the corresponding region (exon 3) and HincII restriction enzyme analysis of all available members proved that there is complete co-segregation of the mutation with the disease in this family (Figure 1).

\section{DisCUSSION}

Ganglioside-induced differentiation-associated protein 1 is a ubiquitously expressed gene with predominant expression in neurons and Schwann cells. The protein product of the GDAP1 has a strong similarity to glutathione S-transferases (GSTs) and two such domains are recognized spanning amino acid residues 26-119 and 210-287. Two putative transmembrane domains are predicted at the C-terminal of the protein. A putative role of GDAP1 in the interaction between Schwann cell and axon has been suggested. ${ }^{6}$ Niemann et $\mathrm{al}^{21}$ (2005) have recently demonstrated that GDAP1 is an integral membrane of the outer mitochondrial membrane and is a regulator of the mitochondrial network.

Twenty-three other GDAP1 mutations have thus far been reported in CMT patients spanning the gene region from codon 92 to $844 .^{5-18}$ These include single base substitutions leading to the introduction of a stop codon (c.92G $>$ A [Trp31stop], c. $487 \mathrm{C}>\mathrm{T}$ [Gln163stop], c.581C $>\mathrm{G}$ [Ser194stop], c.668T >A [Leu223stop]), single base substitutions leading to a splice site mutation (c.311-1G >A, c.579+1G >A), single base substitutions leading to a missense mutation (c.347T $>\mathrm{G}$ [Met116Arg], c.358C $>\mathrm{T}$ [Arg120Trp], c.359G $>\mathrm{A}$ [Arg120GLN], c.389C $>\mathrm{G}$ [Ser130Cys], c.445G $>$ T [Asp149Tyr], c.469A $>$ C [Thr157Pro], c. $482 \mathrm{G}>\mathrm{A}$ [Arg161His], c.715C $>\mathrm{T}$ [Leu239Phe], c.811G $>\mathrm{A}$ [Gly271Arg], c.844C >T [Arg282Cys], c.929G >A [Arg310Gln]) and small deletions or insertions leading to a frame shift mutation (c.341_344delAAAG [Glu114fs], c.349_350insT [Tyr117fs], c.485-2A>G [Ser162fsX166], c.558delT [Ile186fs], c.786delG [Gly262fs], c.863insA [Thr288fs]). The position and type of the above mutations does not appear to have any obvious correlation with the CMT phenotype (ie axonal, demyelinating, intermediate or axonal with vocal cord paresis).

We report a novel GDAP1 gene mutation (439delA) in a consanguineous AR-CMT family, which most probably results in an alteration in GDAP1 from amino acid 147 and it is predicted that a premature termination occurs subsequent to amino acid 151. The reported mutation T147fsX151 does not lie in a known functional domain of GDAP1, however it appears to be within a conserved part of the protein, and it most probably truncates GDAP1 removing the C terminal GST and the two putative transmembrane domains. Niemann et $\mathrm{al}^{21}$ (2005) demonstrated that the T288fs290X and S194X truncated GDAP1 proteins were not targeted efficiently to mitochondria. The shortest Q163X construct was not detectable and the authors speculate that a highly unstable protein is generated by the mutation. We assume that similarly, the hereby reported truncating GDAP1 mutation most probably results in a protein that lacks the $\mathrm{C}$ terminal mitochondrial-targeting signal.

The reported novel mutation is associated with AR-CMT in our family. Although phenotypic variability caused by a GDAP1 mutation within the same family has been previously reported, the variability of neurophysiological data observed between these two patients may also be related to different stages in the course of the disease.

The mechanism by which the same mutation causes a different pathology within the same family remains to be elucidated. The number of known GDAP1 mutations is relatively small to be able to make reliable genotype-phenotype correlations. Further reported cases with GDAP1 mutations, along with detailed clinical, electrophysiological and pathological data, may provide an explanation for the intrafamilial and interfamilial variability in the pathological and electrophysiological findings associated with the different mutations in the GDAP1 gene.

\section{ACKNOWLEDGEMENTS}

We thank the family for their kind participation in our study of CMT disease. This study was supported by the Muscular Dystrophy Association of the USA (grant to K. Christodoulou). 


\section{REFERENCES}

1. Dyck PJ, Chance P, Lebo R, Carney JA. Hereditary motor and sensory neuropathies. In: Dyck PJ, Thomas PK, Griffin JW, Low PA, Poduslo JF, editors. Peripheral Neuropathy. Philadelphia: Saunders; 1993: p. 1094-136.

2. Bouche P, Gherardi R, Cathala HP, Lhermitte F, Castaigne P. Peroneal muscular atrophy. Part 1. Clinical and electrophysiological study. J Neurol Sci. 1983; 61: 389-99.

3. Harding AE, Thomas PK. Genetic aspects of hereditary motor and sensory neuropathy (types I and II). J Med Genet. 1980; 17: 329-36.

4. Berger P, Young P, Suter U. Molecular cell biology of CharcotMarie-Tooth disease. Neurogenetics. 2002; 4: 1-15.

5. Baxter RV, Ben Othmane K, Rochelle JM, Stajich JE, Hulette C, Dew-Knight $\mathrm{S}$, et al. Ganglioside-induced differentiationassociated protein-1 is mutant in Charcot-Marie-Tooth disease type 4A/8q21. Nat Genet. 2002; 30: 21-2.

6. Cuesta A, Pedrola L, Sevilla Garcia-Planells J, Chumillas MJ, Mayordomo F, et al. The gene encoding ganglioside-induced differentiation-associated protein 1 is mutated in axonal CharcotMarie-Tooth type 4A disease. Nat Genet. 2002; 30: 22-4.

7. Birouk N, Azzedine H, Dubourg O, Muriel MP, Benomar A, Hamadouche T, et al. Phenotypical features of a Moroccan family with autosomal recessive Charcot-Marie-Tooth disease associated with the S194X mutation in the GDAP1 gene. Arch Neurol. 2003; 60: 598-604.

8. Claramunt R, Pedrola L, Sevilla T, Lopez de Munain A, Berciano J, Cuesta A, et al. Genetics of Charcot-Marie-Tooth disease type 4A: mutations, inheritance, phenotypic variability, and founder effect. J Med Genet. 2005; 42: 358-65.

9. Nelis E, Erdem S, Van Den Bergh PY, Belpaire-Dethiou MC, Ceuterick C, Van Gerwen V, et al. Mutations in GDAP1: autosomal recessive CMT with demyelination and axonopathy. Neurology. 2002; 59: 1865-72.

10. Senderek J, Bergmann C, Ramaekers VT, Nelis E, Bernert G, Makowski A, et al. Mutations in the ganglioside-induced differentiation-associated protein-1 (GDAP1) gene in intermediate type autosomal recessive Charcot-Marie-Tooth neuropathy. Brain. 2003; 126: 642-9.

11. Boerkoel CF, Takashima H, Nakagawa M, Izumo S, Armstrong D, Butler I, et al. CMT4A: identification of a Hispanic GDAP1 founder mutation. Ann Neurol. 2003; 53: 400-5.

12. Azzedine H, Ruberg M, Ente D, Gilardeau C, Perie S, Wechsler B, et al. Variability of disease progression in a family with autosomal recessive CMT associated with a S194X and new R310Q mutation in the GDAP1 gene. Neuromuscul Disord. 2003; 13: 341-6.

13. Ammar N, Nelis E, Merlini L, Barisic N, Amouri R, Ceuterick C, et al. Identification of novel GDAP1 mutations causing autosomal recessive Charcot-Marie-Tooth disease. Neuromuscul Disord. 2003; 13: 720-8.

14. De Sandre-Giovannoli A, Chaouch M, Boccaccio I, Bernard R, Delague V, Grid D, et al. Phenotypic and genetic exploration of severe demyelinating and secondary axonal neuropathies resulting from GDAP1 nonsense and splicing mutations. J Med Genet. 2003: e87.

15. Di Maria E, Gulli R, Balestra P, Cassandrini D, Pigullo S, DoriaLamba L, et al. A novel mutation of GDAP1 associated with Charcot-Marie-Tooth disease in three Italian families: evidence for a founder effect. J Neurol Neurosurg Psychiatry. 2004; 75: 1495-8.

16. Parman Y, Battaloglu E, Baris I, Bilir B, Poyraz M, Bissar-Tadmouri $\mathrm{N}$, et al. Clinicopathological and genetic study of early-onset demyelinating neuropathy. Brain. 2004; 127: 2540-50.

17. Stojkovic T, Latour P, Viet G, de Seze J, Hurtevent JF, Vandenberghe A, et al. Vocal cord and diaphragm paralysis, as clinical features of a French family with autosomal recessive Charcot-Marie-Tooth disease, associated with a new mutation in the GDAP1 gene. Neuromuscul Disord. 2004; 14: 261-4.
18. Kabzinska D, Kochanski A, Drac H, Ryniewicz B, RowinskaMarcinska K, Hausmanowa-Petrusewicz I. Autosomal recessive axonal form of Charcot-Marie-Tooth Disease caused by compound heterozygous 3'-splice site and Ser130Cys mutation in the GDAP1 Gene. Neuropediatrics. 2005; 36: 206-9.

19. Christodoulou K, Kyriakides T, Hristova AH, Georgiou DM, Kalaydjieva L, Yshpekova B, et al. Mapping of a distal form of spinal muscular atrophy with upper limb predominance to chromosome 7p. Hum Mol Genet. 1995; 4: 1629-32.

20. Lathrop GM, Lalouel JM, Julier C, Ott J. Multilocus linkage analysis in humans: detection of linkage and estimation of recombination. Am J Hum Genet. 1985; 37: 482-98.

21. Niemann A, Ruegg M, La Padula V, Schenone A, Suter U. Ganglioside-induced differentiation associated protein 1 is a regulator of the mitochondrial network: new implications for Charcot-Marie-Tooth disease. J Cell Biol. 2005; 170: 1067-78.

22. Ben Othmane K, Hentati F, Lennon F, Ben Hamida C, Blel S, Roses $\mathrm{AD}$, et al. Linkage of a locus (CMT4A) for autosomal recessive Charcot-Marie-Tooth disease to chromosome 8q. Hum Mol Genet. 1993; 2: 1625-8.

23. Quattrone A, Gambardella A, Bono F, Aguglia U, Bolino A, Bruni $\mathrm{AC}$, et al. Autosomal recessive hereditary motor and sensory neuropathy with focally folded myelin sheaths: clinical, electrophysiologic, and genetic aspects of a large family. Neurology. 1996; 46: 1318-24.

24. Bolino A, Brancolini V, Bono F, Bruni A, Gambardella A, Romeo G, et al. Localization of a gene responsible for autosomal recessive demyelinating neuropathy with focally folded myelin sheaths to chromosome 11q23 by homozygosity mapping and haplotype sharing. Hum Mol Genet. 1996; 5: 1051-4.

25. Bolino A, Muglia M, Conforti FL, LeGuern E, Salih MA, Georgiou DM, et al. Charcot-Marie-Tooth type 4B is caused by mutations in the gene encoding myotubularin-related protein-2. Nat Genet. 2000; 25: 17-9.

26. Gambardella A, Bolino A, Muglia M, Valentino P, Bono F, Oliveri $\mathrm{RL}$, et al. Genetic heterogeneity in autosomal recessive hereditary motor and sensory neuropathy with focally folded myelin sheaths (CMT4B). Neurology. 1998; 50: 799-801.

27. Ben Othmane K, Johnson E, Menold M, Graham FL, Hamida MB, Hasegawa $\mathrm{O}$, et al. Identification of a new locus for autosomal recessive Charcot-Marie-Tooth disease with focally folded myelin on chromosome 11p15. Genomics. 1999; 62: 344-9.

28. Senderek J, Bergmann C, Weber S, Ketelsen UP, Schorle H, Rudnik-Schoneborn S, et al. Mutation of the SBF2 gene, encoding a novel member of the myotubularin family, in CharcotMarie-Tooth neuropathy type 4B2/11p15. Hum Mol Genet. 2003; 12: $349-56$

29. Gabreels-Festen A, van Beersum S, Eshuis L, LeGuern E, Gabreels F, van Engelen B, et al. Study on the gene and phenotypic characterisation of autosomal recessive demyelinating motor and sensory neuropathy (Charcot-Marie-Tooth disease) with a gene locus on chromosome 5q23-q33. J Neurol Neurosurg Psychiat. 1999; 66: 569-74.

30. LeGuern E, Guilbot A, Kessali M, Ravise N, Tassin J, Maisonobe T, et al. Homozygosity mapping of an autosomal recessive form of demyelinating Charcot-Marie-Tooth disease to chromosome 5q23-q33. Hum Mol Genet. 1996; 5: 1685-8.

31. Senderek J, Bergmann C, Stendel C, Kirfel J, Verpoorten N, De Jonghe $\mathrm{P}$, et al. Mutations in a gene encoding a novel SH3/TPR domain protein cause autosomal recessive Charcot-Marie-Tooth type 4C neuropathy. Am J Hum Genet. 2003; 73: 1106-19.

32. Kalaydjieva L, Hallmayer J, Chandler D, Savov A, Nikolova A, Angelicheva D, et al. Gene mapping in Gypsies identifies a novel demyelinating neuropathy on chromosome 8q24. Nat Genet. 1996; 14: 214-7.

33. Kalaydjieva L, Gresham D, Gooding R, Heather L, Baas F, de Jonge $\mathrm{R}$, et al. N-myc downstream-regulated gene 1 is mutated in hereditary motor and sensory neuropathy-Lom. Am J Hum Genet. 2000; 67: 47-58. 
34. Warner LE, Mancias P, Butler IJ, McDonald CM, Keppen L, Koob $\mathrm{KG}$, et al. Mutations in the early growth response 2 (EGR2) gene are associated with hereditary myelinopathies. Nat Genet. 1998; 18: 382-4.

35. Delague V, Bareil C, Tuffery S, Bouvagnet P, Chouery E, Koussa S, et al. Mapping of a new locus for autosomal recessive demyelinating Charcot-Marie-Tooth disease to $19 \mathrm{q} 13.1-13.3$ in a large consanguineous Lebanese family: exclusion of MAG as a candidate gene. Am J Hum Genet. 2000; 67: 236-43.

36. Guilbot A, Williams A, Ravise N, Verny C, Brice A, Sherman DL, et al. A mutation in periaxin is responsible for CMT4F, an autosomal recessive form of Charcot-Marie-Tooth disease. Hum Mol Genet. 2001; 10: 415-21.

37. Thomas PK, Kalaydjieva L, Youl B, Rogers T, Angelicheva D, King $\mathrm{RH}$, et al. Hereditary motor and sensory neuropathy-Russe: new autosomal recessive neuropathy in Balkan Gypsies. Ann Neurol. 2001; 50: 452-7.

38. De Sandre-Giovannoli A, Delague V, Hamadouche T, Chaouch M, Krahn M, Boccaccio I, et al. Homozygosity mapping of autosomal recessive demyelinating Charcot-Marie-Tooth neuropathy (CMT4H) to a novel locus on chromosome 12p11.21q13.11. J Med Genet. 2005; 42: 260-5.

39. Bouhouche A, Benomar A, Birouk N, Mularoni A, Meggouh F, Tassin J, et al. A locus for an axonal form of autosomal recessive Charcot-Marie-Tooth disease maps to chromosome 1q21.2q21.3. Am J Hum Genet. 1999; 65: 722-7.
40. De Sandre-Giovannoli A, Chaouch M, Kozlov S, Vallat JM, Tazir M, Kassouri N, et al. Homozygous defects in LMNA, encoding lamin A/C nuclear-envelope proteins, cause autosomal recessive axonal neuropathy in human (Charcot-Marie-Tooth disorder type 2) and mouse. Am J Hum Genet. 2002; 70: 726-36.

41. Leal A, Morera B, Del Valle G, Heuss D, Kayser C, Berghoff M, et al. A second locus for an axonal form of autosomal recessive Charcot-Marie-Tooth disease maps to chromosome 19q13.3. Am J Hum Genet. 2001; 68: 269-74.

42. Berghoff C, Berghoff M, Leal A, Morera B, Barrantes R, Reis A, et al. Clinical and electrophysiological characteristics of autosomal recessive axonal Charcot-Marie-Tooth disease (ARCMT2B) that maps to chromosome 19q13.3. Neuromusc Disord. 2004; 14: 301-6.

43. Barhoumi C, Amouri R, Ben Hamida C, Ben Hamida M, Machghoul S, Gueddiche M, et al. Linkage of a new locus for autosomal recessive axonal form of Charcot-Marie-Tooth disease to chromosome 8q21.3. Neuromusc Disord. 2001; 11: 27-34.

44. Sevilla T, Cuesta A, Chumillas MJ, Mayordomo F, Pedrola L, Palau F, et al. Clinical, electrophysiological and morphological findings of Charcot-Marie-Tooth neuropathy with vocal cord palsy and mutations in the GDAP1 gene. Brain. 2003; 126: 2023-33. 